\title{
Outstanding HC-SCR of Lean NOx Over Pt/Mesoporous-Silica Catalysts
}

\author{
Tamikuni Komatsu*, Keizou Tomokuni, Mitsuo Konishi and Takashi Shirai
}

The Noguchi Institute, Asahi-Kasei Corporation, 1-8-1 Kaga, Itabashi-Ku, Tokyo 173-0003, Japan

\begin{abstract}
Perfect de-NOx over a wide temperature range above $170{ }^{\circ} \mathrm{C}$ was achieved using a new Pt-catalyst supported on mesoporous silica (Pt/MPS) and a stoichiometric amounts of long-chain hydrocarbons as reducing agents for NOxpurification. Kinetic investigation of the HC-SCR of lean NOx over Pt/MPS, Pt/alumina and Pt/zirconia showed that such a remarkable activity of Pt/MPS is due to a large frequency factor but not to activation energy. Acid-treatment of the supports increased the activities of the catalysts and generated new IR-peaks in the range $1000-1200 \mathrm{~cm}^{-1}$, which suggests the support-effects on the catalyst-activities to be related to the special surface functional groups of the supports. The present HC-SCR must be very useful to remove diesel-NOx by means of pulse-injection of diesel fuel into the exhaust.
\end{abstract}

Keywords: HC-SCR, lean NOx, de-NOx, diesel exhaust, mesoporous, mesoporous silica, diesel fuel.

\section{INTRODUCTION}

The regulation of greenhouse warming due to $\mathrm{CO}_{2}$ discharged by automobiles has become quite severe all over the world. To decrease $\mathrm{CO}_{2}$ emission, changes such as gasoline-autos into diesel-autos with higher fuel efficiency have been expected. However, how to purify diesel-NOx is still unresolved. The $\mathrm{O}_{2}$-content of the gasoline-exhaust is controlled below $0.5 \%$ (rich burn) but the $\mathrm{O}_{2}$-content of the diesel-exhaust is usually $24 \% \mathrm{O}_{2}$ (lean burn). This makes purification of the diesel-NOx very difficult, because of immediate deactivation of the conventional three-way catalysts by oxygen at $1 \%$. Also, comparatively low temperatures of the diesel-exhaust which are usually 100 $400{ }^{\circ} \mathrm{C}$ make purification very difficult because of the low activities of the conventional catalysts below $200{ }^{\circ} \mathrm{C}$. Dieselfuel consists of $\mathrm{C}_{6}-\mathrm{C}_{16} \mathrm{HCs}$ including aromatic compounds. However, the fuel was not directly used as the reducing agents because of low reducing performance, while a usage of diesel-fuel for reduction of NOx is essentially necessary for such de-NOx catalysts as remove NOx by means of pulse-injection of diesel-fuel into the exhaust.

The recent de-NOx methods such as the urea-SCR and NOx-storage-reduction (LNT: lean-Nox-trap) were reviewed [1]: (1) the urea-SCR has unresolved problems that the method requires storing a solution of urea and that a large portion of NOx may be discharged in the form of nitrates and nitrites at low temperatures; (2) the LNT has essential problems such as deactivation of NOx-storage agents by a small SOx-content and very low activities below $200{ }^{\circ} \mathrm{C}$. The other method, the HC-SCR [2-6] has a problem that the purification is limited to narrow temperature ranges around $200{ }^{\circ} \mathrm{C}$, although the catalysts are free from deactivation by SOx [7]. To improve the HC-SCR method, the presentation of Pt-catalysts supported on MCM-41 type mesoporous silica [8], the intermediate addition of reducing agents [9], a secondary fuel-injection method [10], a double-

*Address correspondence to this author at 2-24-4 Sakura, Tsukuba-shi, Ibaraki 305-0003, Japan; Tel: +81 29-857-7325; Fax: +81 29-857-7325; E-mail: BRA01367@nifty.com washed honeycomb coating with two kinds of Pt-catalysts [11], and a fast SCR process [12] were studied. However, the HC-SCR method has not been considered for mainstream lean burn NOx-purification, because of the low activities of the catalysts below $200{ }^{\circ} \mathrm{C}$ and a narrow temperature window.

Previously, we presented outstanding low-temperature active Pt/MPS to purify diesel-NOx exhaust [13]. The present study will report the kinetics of HC-SCR of NOx over Pt/MPS and an application to perfect purification of diesel-NOx in a wide temperature range over $170{ }^{\circ} \mathrm{C}$ with diesel-fuel.

\section{MATERIALS AND METHODOLOGY}

\section{Sample Preparation}

Mesoporous silica (MPS) was prepared by a sol-gel method using tetraethyl orthosilicate (TEOS) as a silicasource and dodecylamine as a template. Pt/MPS was prepared by impregnating MPS with an aqueous solution of $\mathrm{H}_{2} \mathrm{PtCl}_{4}$ as the Pt-source. The experimental details were described in the previous report [13]. For comparison, $\mathrm{Pt} /$ silica, $\mathrm{Pt} /$ silica-alumina, $\mathrm{Pt} /$ alumina, $\mathrm{Pt} /$ zirconia and a NOx-absorption-reduction catalyst (LNT) were prepared in a similar manner as above using commercially available support-materials. The precious metal loading was 5 mass \% $\mathrm{Pt}$ and 0.3 mass \% Rh for Pt/MPS, and 2 mass \% $\mathrm{Pt}$ and 0.12 mass \% Rh for $\mathrm{Pt} /$ silica, $\mathrm{Pt} /$ silica-alumina, Pt/alumina and $\mathrm{Pt} /$ zirconia. The LNT was $2 \% \mathrm{Pt}-0.12 \% \mathrm{Rh} /$ alumina $(80 \%)$ ceria (10\%)-zirconia (10\%) including $\mathrm{BaCO}_{3}(3 \%), \mathrm{La}_{2} \mathrm{O}_{3}$ $(1 \%)$ and $\mathrm{KOH}(1 \%)$. In addition, Pt-catalysts using acidtreated supports of MPS, $\gamma$-alumina and zirconia were also prepared. The acid-treatment of the supports was carried out as follows: boiling in a 0.1 mass $\%$ solution of equimolar $\mathrm{HNO}_{3}$ and $\mathrm{H}_{2} \mathrm{SO}_{4}$ for $3 \mathrm{~h}$, followed by washing with distilled water. A honeycomb catalyst was prepared using the Pt/MPS powders as follows: a slurry of the Pt/MPS powders mixed with alumina-sol was prepared, coated on a full-size cordierite-honeycomb $(\varphi 143.8 \mathrm{~mm} \times 118 \mathrm{~mm}, 4.5 \mathrm{mil} / 400$ cpsi), followed by calcination at $600{ }^{\circ} \mathrm{C}$ for $1 \mathrm{~h}$ in air. A coating mass of Pt/MPS was $80 \mathrm{~g}$ per 1 liter of the 
honeycomb. Assessment of the heat-resistance of Pt/MPS was carried out using the sample after the heat-treatment under each condition of $600{ }^{\circ} \mathrm{C}-50 \mathrm{~h}, 700{ }^{\circ} \mathrm{C}-50 \mathrm{~h}$ and 800 ${ }^{\circ} \mathrm{C}-50 \mathrm{~h}$ in air containing $10 \%$ steam.

\section{Characterization of the Samples}

The specific surface areas and pore sizes of the supports were measured using nitrogen adsorption at $77 \mathrm{~K}$. The porestructure of the supports was characterized by small-angle Xray diffraction (SAX) and selected-area electron diffraction (SAED). Exposed active sites of Pt/MPS for estimation of turn over frequency (ToF) were measured by $\mathrm{CO}$ chemisorption. Crystallite sizes of the catalysts were directly measured by high-resolution TEM (HRTEM) observation. The average size of the crystallites was estimated from the half-width of the (111) reflection by powder XRD measurements. Homogeneities of the supported catalysts were confirmed by HRTEM observations.

\section{Measurements of HC-SCR of NOx}

The experiment of HC-SCR of NOx was carried out using a three-necked quartz tubular downflow reactor (20 $\mathrm{mm}$ i.d and $400 \mathrm{~mm}$ length). A mini honeycomb-catalyst (2 $\mathrm{ml}$ in volume) or powder catalyst was charged into the reactor, a small amount of glass wool was placed on the catalyst, and $10 \mathrm{ml}$ of sea-sand ${ }^{1}$ as a dispersant of reaction gases was placed on the glass wool to initiate the reaction over the catalyst in a homogeneous reaction gas flow. The mini honeycomb catalyst was cut from the full-size honeycomb catalyst. The powder catalyst (160 mg of 5\% Ptcatalysts or $400 \mathrm{mg}$ of $2 \%$ Pt-catalysts) was mixed in advance with commercially available sea-sand (20-30 mesh) at $2.6 \mathrm{~g}(2 \mathrm{ml})$ and charged into the reactor. The reactor containing the catalyst was placed in an electric furnace. As an exhaust gas for NOx-purification experiments, three model-gases, (1) a reaction mixture comprising $250 \mathrm{ppm}$ $\mathrm{NO}, 400 \mathrm{ppm} \mathrm{C}_{3} \mathrm{H}_{6}$ and $10 \% \mathrm{O}_{2}$ balanced with $\mathrm{He}$, (2) a reaction mixture comprising $250 \mathrm{ppm} \mathrm{NO}_{2}, 400 \mathrm{ppm} \mathrm{C}_{3} \mathrm{H}_{6}$ and $10 \% \mathrm{O}_{2}$ balanced with $\mathrm{He}$, (3) a reaction mixture comprising 250 ppm NO, 2000-7000 ppm liquid of long chain $\mathrm{HCs}$ and $10 \% \mathrm{O}_{2}$ balanced with $\mathrm{He}$, were used. Each model-gas was introduced into a gas-inlet of the reactor at a flow rate of $1000 \mathrm{ml} \mathrm{min}^{-1}\left(\mathrm{SV}=30,000 \mathrm{~h}^{-1}\right.$ or $\mathrm{GHSV}=7.5 \mathrm{~m}^{3}$ $\mathrm{h}^{-1}$ per $\mathrm{g}$ of $\mathrm{Pt}$ ) through a mass-flow controller. The liquid HCs were supplied upstream along the inner wall of the reactor by a syringe-type micro-feeder. The temperature of the reactor was increased at a rate of about $10{ }^{\circ} \mathrm{C} \mathrm{min}-1$ and was held at the prescribed temperature for $10 \mathrm{~min}$. The NOx measurement of the effluent gas was carried out during a period held at the prescribed temperature using a chemiluminescence NOx-detector ${ }^{2}$. To confirm the mechanism of the HC-SCR, two reactors containing the honeycomb catalyst were connected in series. The first stage (oxidation of $\mathrm{NO}$ into $\mathrm{NO}_{2}$ with $\mathrm{O}_{2}$ ) was carried out by introducing a reaction mixture of $250 \mathrm{ppm} \mathrm{NO}$ and $10 \% \mathrm{O}_{2}$ balanced with $\mathrm{He}$ into the gas-inlet of the first-stage reactor at a flow rate of $1000 \mathrm{ml} \mathrm{m^{-1 }}\left(\mathrm{SV}=30,000 \mathrm{~h}^{-1}\right)$ and the

\footnotetext{
${ }^{1}$ Sea-sand (quartz-sand) is generally used as a dispersant because of inactivity in catalysis.

${ }^{2}$ The diminished-pressure chemiluminescence NOx detector, Japan Thermo Corp. Model $42 \mathrm{i}-\mathrm{HL} \& 46 \mathrm{C}-\mathrm{H}$, which performs simultaneous detection of $\mathrm{NO}, \mathrm{NO}_{2}$ and $\mathrm{N}_{2} \mathrm{O}$ contained in the effluent gas.
}

second stage (reduction of NOx with propylene) was carried out by introducing $400 \mathrm{ppm}_{3} \mathrm{H}_{6}$ into the gas-inlet of the second-stage reactor at a flow rate of $1000 \mathrm{ml} \mathrm{min}^{-1}$. The result was analyzed using the experimental NOx-conversion and $\mathrm{NO}: \mathrm{NO}_{2}$ ratio ${ }^{3}$.

\section{RESULTS AND DISCUSSION}

\section{Characterization of the Pt-Catalysts}

Table 1 shows the characterization of the used Pt-catalysts and supports. The SAX profile of MPS showed a strong singletpeak at $2 \theta=2.72^{\circ}(d=3.25 \mathrm{~nm})$. The SAED image showed a hallow pattern. The results mean that MPS is completely disordered in the pore-arrangement differently from wellordered MCM-41. The specific surface area and pore diameter of MPS were $1250 \mathrm{~m}^{2} \mathrm{~g}^{-1}$ and $2.5 \mathrm{~nm}$, respectively. An estimated thickness of mesopore-walls for MPS was ca. $2 \mathrm{~nm}$, which is about twice larger than that for MCM-41. Relative IRintensity around at $3400 \mathrm{~cm}^{-1}$ showed that MPS is covered with minor amount of hydrolytic $\mathrm{OH}$-groups in comparison to MCM-41. The exposed active site of Pt/MPS which was estimated from the experimental CO-chemisorption was ca. 5\%. The HRTEM image of Pt/MPS indicated that many Pt-particles of 1-3 nm in diameter are homogeneously dispersing on the support surface. The average diameter of the Pt-particles was 2 $\mathrm{nm}$ which is very close to the pore diameter of MPS. This indicates the Pt-particles of the catalyst to be supported in the inside of mesopores. On the other hand, those for Pt/alumina, $\mathrm{Pt} /$ silica-alumina, Pt/silica, LNT and Pt/zirconia were 2, 4, 5, 6 and $21 \mathrm{~nm}$, respectively. Since the average diameter of $\mathrm{Pt} /$ silicaalumina is smaller than the pore diameter, the Pt-particles of the catalyst may be in the inside of mesopores. However for $\mathrm{Pt} /$ silica and Pt/zirconia, the Pt-particles are supported in the outside of mesopores. Also, the Pt-particles of Pt/alumina and LNT may be supported in the outside of mesopores, because adsorption ability of $\gamma$-alumina is much stronger than those of the other supports.

Table 1. Characterization of the Used Pt-Catalysts (Powders) and Supports

\begin{tabular}{|l|c|c|c|}
\hline \multirow{2}{*}{ Pt-Catalysts } & \multirow{2}{*}{$\begin{array}{c}\text { Pt-Particles } \\
\text { Average } \\
\text { Diameter/nm }\end{array}$} & $\begin{array}{c}\text { Specific } \\
\text { Surface } \\
\text { Area/ } \mathbf{m}^{2} \mathbf{g}^{-1}\end{array}$ & $\begin{array}{c}\text { Pore } \\
\text { Diameter/nm }\end{array}$ \\
\cline { 3 - 4 } & & 1250 & 2.5 \\
Pt/MPS & 2 & 428 & non-porous \\
Pt/Silica & 5 & 412 & 3.8 \\
Pt/Silica-Alumina & 4 & 250 & 6.2 \\
Pt/Alumina & 2 & 128 & 7 \\
Pt/Zirconia & 21 & 210 & $6-20$ \\
LNT Type Catalyst & 6 &
\end{tabular}

\section{Heat-Resistance of MPS and Pt/MPS}

The specific surface areas and poresizes of MPS before and after the heat-treatment at $700{ }^{\circ} \mathrm{C}-50 \mathrm{~h}$ in air containing

\footnotetext{
${ }^{3}$ From the experimental $\mathrm{NOx}-$ conversion and $\mathrm{NO}: \mathrm{NO}_{2}$ ratio, contribution of $\mathrm{NO}$ or $\mathrm{NO}_{2}$ to the NOx-conversion can be estimated, since NOxconversion is defined as the conversion of $\mathrm{NOx}$ (total of $\mathrm{NO}$ and $\mathrm{NO}_{2}$ ) into nonhazardous $\mathrm{N}$-containing compounds such as $\mathrm{N}_{2}$ and $\mathrm{N}_{2} \mathrm{O}$.
} 
$10 \%$ steam were almost unchanged. The hydrothermal durability of MPS was much higher than that of MCM-41. According to our experiment, MCM-41 lost half of the specific surface area and mesopores after ageing at $600{ }^{\circ} \mathrm{C}$ $24 \mathrm{~h}$ in air containing $10 \%$ steam. Probably the high heatresistance of MPS is due to the thick mesopore-walls and minor amounts of hydrolytic OH-groups, because under hydrothermal conditions $\mathrm{H}_{2} \mathrm{O}$ molecules attacks -Si-Oskeletons to destroy mesoporous structures. Fig. (1) shows the relationship between $\mathrm{NOx}$-conversion and ageing conditions for Pt/MPS. Until $600{ }^{\circ} \mathrm{C}-50 \mathrm{~h}$, a maximum NOx conversion $(70 \%)$ and corresponding temperature (the lower limit in temperature: $170{ }^{\circ} \mathrm{C}$ ) were similar to those of fresh $\mathrm{Pt} / \mathrm{MPS}$. After $700{ }^{\circ} \mathrm{C}-50 \mathrm{~h}$, the NOx conversion was not changed but the lower limit in temperature rose to $210{ }^{\circ} \mathrm{C}$ $\left(40{ }^{\circ} \mathrm{C}\right.$ rise). After $800{ }^{\circ} \mathrm{C}-50 \mathrm{~h}$, the NOx conversion dropped to $45 \%$ (25\% drop) and the lower limit in temperature rose to $230{ }^{\circ} \mathrm{C}\left(60{ }^{\circ} \mathrm{C}\right.$ rise $)$. In order to elucidate whether such a higher temperature shift is due to permanent deterioration or not, the heat-treated Pt/MPS was reduced with hydrogen at $300{ }^{\circ} \mathrm{C}-1 \mathrm{~h}$, followed by the same HC-SCR of NOx. The result showed remarkable restoration close to the temperature for fresh Pt/MPS. On the other hand, the powder XRD measurements of the heat-treated Pt/MPS showed that an averaged size of Pt-particles was scarcely changed until $600{ }^{\circ} \mathrm{C}-50 \mathrm{~h}$, increased to $4-5 \mathrm{~nm}$ (3 times larger than that of fresh Pt/MPS) after $700{ }^{\circ} \mathrm{C}-50 \mathrm{~h}$, remarkably increased to 10 $\mathrm{nm}$ after $800{ }^{\circ} \mathrm{C}-50 \mathrm{~h}$. The result teaches that the higher temperature shift for the heat-treated Pt/MPS is due to both oxidation and enlargement of the supported Pt-particles. The former factor may be gradually restored by reduction with HCs contained in rich burn exhausts and the latter greatly influences the activity of the catalyst over $800{ }^{\circ} \mathrm{C}$. A similar relationship between the $\mathrm{Pt}$-size and ageing conditions was observed for conventional Pt/alumina. The high heat resistance of $\mathrm{Pt} / \mathrm{MPS}$ is found due to mechanically strong encapsulation in the mesopores which is different from chemically strong adsorptive ability of $\gamma$-alumina supports, because MPS is much inferior to $\gamma$-alumina with respect to adsorptive ability. The activity of $\mathrm{Pt} / \mathrm{MPS}$ remaining after ageing at $700{ }^{\circ} \mathrm{C}-50 \mathrm{~h}$ corresponds to an estimation of a million km-traveling on the heavy duty diesel cars, on the basis of the Arrhenius plots (the logarithm of ageing hour vs $1 / \mathrm{T}$ relationships in the range $400-700{ }^{\circ} \mathrm{C}$ ).

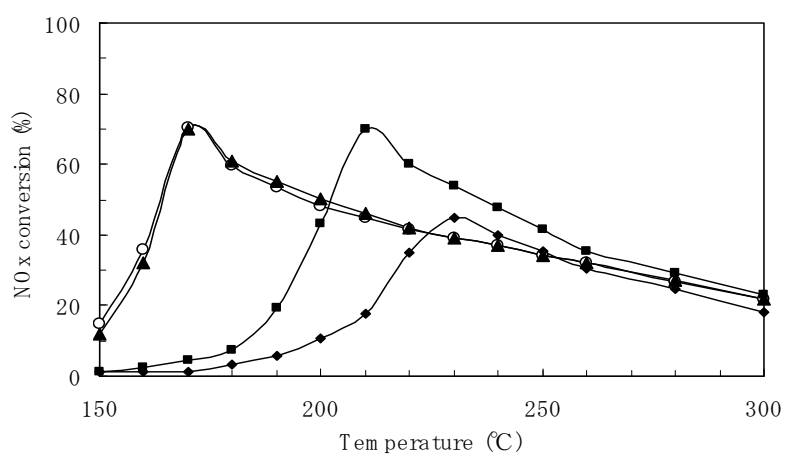

Fig. (1). The heat-resistance of Pt/MPS (powders): (0) fresh; ( $\mathbf{\Delta})$ after $600{ }^{\circ} \mathrm{C}-50 \mathrm{~h}$ in air containing $10 \%$ steam; (匹) after $700{ }^{\circ} \mathrm{C}-50$ $\mathrm{h}$ in air containing $10 \%$ steam; $(\diamond)$ after $800{ }^{\circ} \mathrm{C}-50 \mathrm{~h}$ in air containing $10 \%$ steam.

\section{Kinetics of HC-SCR of Lean-NOx over the Pt-Catalysts with Propylene}

Fig. (2) shows the NOx-conversion over Pt/MPS, $\mathrm{Pt} /$ alumina and $\mathrm{Pt} /$ zirconia using model-gas (1). Pt/MPS provides a peak NOx-conversion of $70 \%$ at $170{ }^{\circ} \mathrm{C}$, while $\mathrm{Pt} /$ alumina and $\mathrm{Pt} /$ zirconia respectively show $40 \%$ at $240{ }^{\circ} \mathrm{C}$ and $33 \%$ at $260{ }^{\circ} \mathrm{C}$. The ToF of Pt/MPS in terms of NOx conversion, which was calculated on the basis of the experimental exposed active sites, was 0.7 at $70 \%$

$\mathrm{NOx}$-conversion. The gas after the treatment was composed of $\mathrm{N}_{2}, \mathrm{~N}_{2} \mathrm{O}, \mathrm{CO}_{2}$ and $\mathrm{H}_{2} \mathrm{O}$, except for unchanged NOx. The selectivity for $\mathrm{N}_{2}$ was $10-30 \%$ below $200{ }^{\circ} \mathrm{C}$ and over $95 \%$ above $250{ }^{\circ} \mathrm{C}$, which was almost the same as the selectivity of the gasoline-auto emission purification over the conventional three-way-catalysts. The curve of NOxconversion before the peak for each catalyst is almost the same as that of NO-conversion, that is, the NOx-conversion is almost the same as the conversion of $\mathrm{NO}_{2}$. After the peak, the NO-conversion continues to increase up to $250{ }^{\circ} \mathrm{C}$ followed by a slight decrease above $250{ }^{\circ} \mathrm{C}$. The NOxconversion tends to decrease after the peak, which means that an increase in $\mathrm{NO}_{2}$ does not contribute to the NOxconversion. This is due to wasteful consumption of propylene above $180{ }^{\circ} \mathrm{C}$, because propylene is very combustible with oxygen. According to our experiment, the conversion of propylene over Pt/MPS with $10 \% \mathrm{O}_{2}$ begins at $100{ }^{\circ} \mathrm{C}$ and increases rapidly at $110{ }^{\circ} \mathrm{C}$, reaching $100 \%$ at $150{ }^{\circ} \mathrm{C}$. Apparent activation energies and frequency factors estimated from the conversion curve were $104 \mathrm{~kJ} \mathrm{~mol}^{-1}$ and $2.4 \times 10^{7} \mathrm{~s}^{-1}$, respectively. The smaller NOx-conversions of $\mathrm{Pt}$ /alumina and Pt/zirconia are not only due to the low activities of the catalysts but also to unselective conversion of propylene above $200{ }^{\circ} \mathrm{C}$.

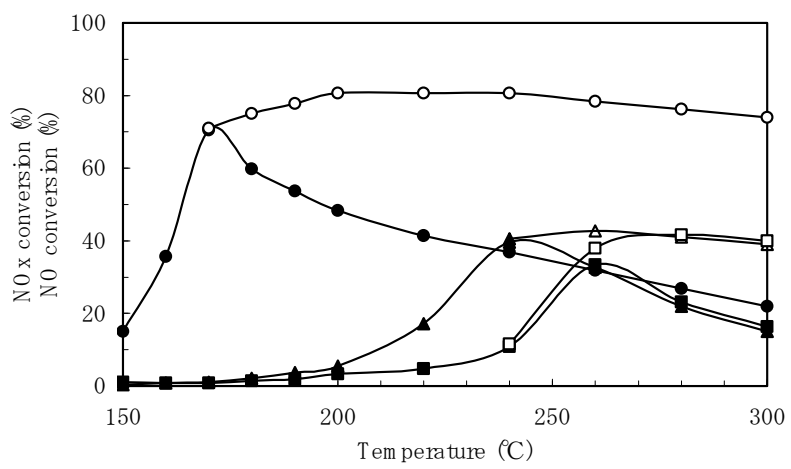

Fig. (2). NOx-conversion over the Pt-catalysts (powders) with model-gas (1): $(\bullet),(\boldsymbol{\Delta})$ and ( $\boldsymbol{\bullet})$ depict the NOx-conversion over Pt/MPS, Pt/alumina and Pt/zirconia, respectively; $(\circ),(\triangle)$ and $(\square)$ depict the NO-conversion over the Pt/MPS, Pt/alumina and $\mathrm{Pt} /$ zirconia, respectively.

Fig. (3) shows the Arrhenius plots (the logarithm of conversion rate $v s 1 / \mathrm{T}$ relationships) of the observed NOxconversions shown in Fig. (2). The obtained apparent activation energies $E$ and frequency factors $A$ are summarized in Table 2. These results show that the E-values for NOx-conversions of Pt/MPS, Pt/alumina and Pt/zirconia are scarcely different. The obtained values are slightly different from those reported previously [14-17] $\left(\mathrm{E}_{\mathrm{NO}}=91.2\right.$ 
$\mathrm{kJ} \mathrm{mol}^{-1}$ and $\mathrm{E}_{\mathrm{C} 3 \mathrm{H} 6}=108.5 \mathrm{~kJ} \mathrm{~mol}^{-1}$ reported by Ioan et al [14]), because of the different reaction conditions. The Avalue of Pt/MPS is larger by at least two orders of magnitude than those of Pt/alumina and Pt/zirconia. Therefore, the difference in activity among the catalysts must be affected by frequency factors rather than activation energies. On the other hand, the Pt-particle size of Pt/MPS is similar to that of $\mathrm{Pt} /$ alumina as shown in Table $\mathbf{1}$. The results suggest that the remarkable low-temperature activity of Pt/MPS is due to the MPS-support.

Table 2. Apparent Activation Energies and Frequency Factors of Pt-Catalysts (Powders) Estimated from Fig. (2)

\begin{tabular}{|l|c|c|c|c|}
\hline \multirow{2}{*}{ Pt-Catalysts } & \multicolumn{2}{|c|}{ NOx-Conversion } & \multicolumn{2}{c|}{$\mathbf{C}_{3} \mathbf{H}_{6}$-Conversion } \\
\cline { 2 - 5 } & $\mathbf{E} / \mathbf{k J} \mathbf{~ m o l}^{-1}$ & $\mathbf{A} / \mathbf{s}^{-1}$ & $\mathbf{E} / \mathbf{k J ~ m o l}^{-1}$ & $\mathbf{A} / \mathbf{s}^{-1}$ \\
\hline \hline Pt/MPS & 102 & $8.6 \times 10^{6}$ & 124 & $1.4 \times 10^{9}$ \\
$\mathrm{Pt} /$ Alumina & 102 & $2.6 \times 10^{4}$ & - & - \\
$\mathrm{Pt} /$ Zirconia & 101 & $5.9 \times 10^{3}$ & - & - \\
\hline
\end{tabular}

Estimations of $\mathrm{E}$ and $\mathrm{A}$ of the $\mathrm{C}_{3} \mathrm{H}_{6}$ conversion for $\mathrm{Pt} /$ alumina and $\mathrm{Pt} /$ zirconia were useless because of wasteful combustion of propylene above $200{ }^{\circ} \mathrm{C}$.

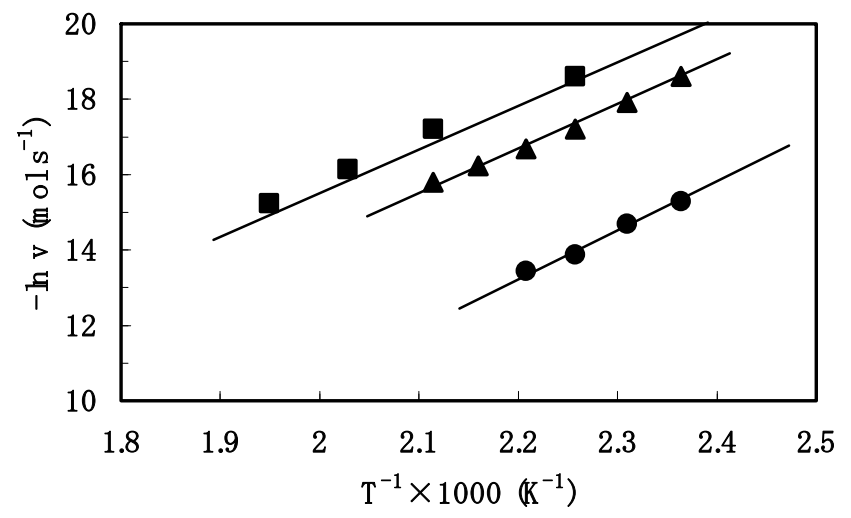

Fig. (3). Arrhenius plots (the logarithm of conversion rate $v s 1 / \mathrm{T}$ relationships) of the observed NOx-conversions over Pt/MPS, Pt/alumina and Pt/zirconia shown in Fig. (2): (•) Pt/MPS; ( $\boldsymbol{\Delta}$ ) Pt/alumina; (a) Pt/zirconia.

\section{The Effects of Supports on NOx-Conversion}

To clarify the above effects of supports to the NOxconversion, acid-treatment of the supports was carried out. Fig. (4) shows the NOx-conversions over the Pt-catalysts using acid-treated $\gamma$-alumina and zirconia. As seen from the comparison with Fig. (2), the acid-treatment of the supports gives a remarkable increase in NOx-conversion and lowtemperature shifts of the peak-temperatures. The acidtreatment of MPS also increases the NOx-conversion by several $\%$. The IR spectra of $\gamma$-alumina and zirconia after the acid-treatment were investigated. Resultantly, new peaks appeared at 1152 and $1065 \mathrm{~cm}^{-1}$ for $\gamma$-alumina and 1211 , 1141 and $1047 \mathrm{~cm}^{-1}$ for zirconia. Since the absorption bands in this finger-print region are generally assigned to the stretching bands of $\mathrm{SiO}_{2}$-skelton, the observed peaks are probably due to protons bonded to the metal oxide skeletons because stretching bands of $\mathrm{Si}-\mathrm{O}$ in $\mathrm{Si}-\mathrm{OH}$ groups are generally known to be observed in the range $800-1000 \mathrm{~cm}^{-1}$.
It is also well-known that a portion of active $\mathrm{OH}$-groups on solid-acids is acting as the Brpnsted-acid sites. Then, the high activity of Pt/MPS and increased activities of $\mathrm{Pt} /$ alumina and $\mathrm{Pt} /$ zirconia using the acid-treated supports are probably due to active protons incorporated with the supports.

\section{Mechanism of the HC-SCR of Lean-NOx}

To elucidate a mechanism of the HC-SCR of NOx over Pt/MPS, the NOx-purification process was formally divided into two stages: (1) [1 ${ }^{\text {st }}$-stage] oxidation of $\mathrm{NO}$ into $\mathrm{NO}_{2}$

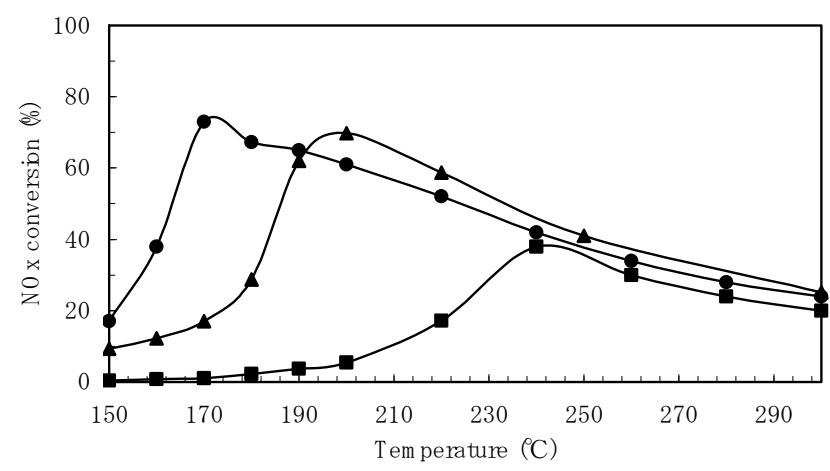

Fig. (4). NOx-conversion over the Pt-catalysts (powders) supported

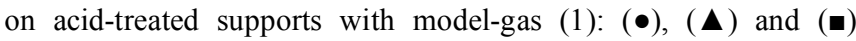
depict the NOx-conversion over Pt/[acid-treated MPS], Pt/[acidtreated alumina] and $\mathrm{Pt} /[$ acid-treated zirconia], respectively.

with $\mathrm{O}_{2},(2)\left[2^{\text {nd }}\right.$-stage $]$ successive reduction of $\mathrm{NO}_{\mathrm{x}}$ with propylene. From Fig. (5a), it is found that Pt/MPS slowly oxidizes $\mathrm{NO}$ to $\mathrm{NO}_{2}$ with $\mathrm{O}_{2}$, because the conversion of $\mathrm{NO}$ to $\mathrm{NO}_{2}$ is much lower than that predicted from the equilibrium. The apparent activation energies and frequency factors estimated from Fig. (5a) were $108 \mathrm{~kJ} \mathrm{~mol}^{-1}$ and $5 \times 10^{4}$ $\mathrm{s}^{-1}$, respectively. Fig. (5b) shows that all of the $\mathrm{NO}_{2}$ produced in the first stage is reduced into $\mathrm{N}_{2} \mathrm{O}$ and $\mathrm{N}_{2}$ below $170{ }^{\circ} \mathrm{C}$, because the $\mathrm{NO}_{2}$ ratio is zero $\%$ from the beginning of reaction $\left(150{ }^{\circ} \mathrm{C}\right)$ to a maximum NOx conversion $(170$ $\left.{ }^{\circ} \mathrm{C}\right)$. Fig. (5c) shows the result of HC-SCR of $\mathrm{NO}_{2}$ over $\mathrm{Pt} / \mathrm{MPS}$ with propylene. The estimated apparent activation energy was $64 \mathrm{~kJ} \mathrm{~mol}^{-1}$. That is, $\left[2^{\text {nd }}\right.$-stage $]$ reduction of $\mathrm{NO}_{2}$ with propylene is very faster than [ ${ }^{\text {st }}$-stage] oxidation of NO into $\mathrm{NO}_{2}$. Therefore, oxidation of $\mathrm{NO}$ into $\mathrm{NO}_{2}$ is the ratedetermining step. The results also notify that $\mathrm{NO}_{2}$-molecules can be purified into $\mathrm{N}_{2} \mathrm{O}$ and $\mathrm{N}_{2}$ over Pt-catalysts with $\mathrm{HCs}$ but NO-molecules are difficult. The appearance of the Brpnsted-acid sites on the acid-treated supports may influence the rate-determining step. If $\mathrm{NO}_{2}$ is more effective for NOx-conversion than $\mathrm{NO}$, the $\mathrm{HC}-\mathrm{SCR}$ of $\mathrm{NO}_{2}$ may be more advantageous than that of NO, as reported in ref. [5]. As shown in Fig. (5c), in spite of the HC-SCR of $\mathrm{NO}_{2}\left(\mathrm{E}_{\mathrm{NOx}}\right.$ $=64 \mathrm{~kJ} \mathrm{~mol}^{-1}$ ) much faster than that of $\mathrm{NO}$, the maximum NOx-conversion $(75 \%)$ and its temperature $\left(170{ }^{\circ} \mathrm{C}\right)$ were not much different from those for the HC-SCR of NO. Reduction of $\mathrm{NO}_{2}$ into $\mathrm{NO}$ quickly occurred around 150-160 ${ }^{\circ} \mathrm{C}$ (the conversion of $\mathrm{NO}_{2}$ into $\mathrm{NO}$ was $77 \%$ at $150{ }^{\circ} \mathrm{C}$ ). That is, the HC-SCR of $\mathrm{NO}_{2}$ over Pt/MPS is also unselective. The following is a reaction diagram of the HCSCR of lean-NOx over Pt/MPS which was confirmed from the results. 




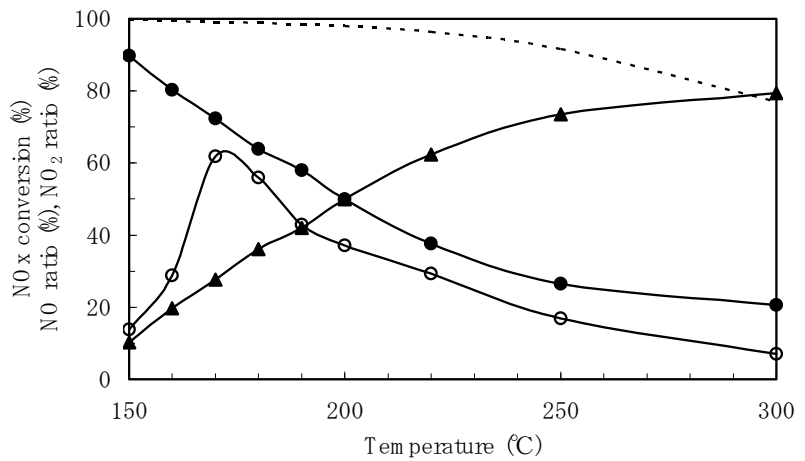

Fig. (5a). $\left[1^{\text {st }}\right.$ stage $]$ oxidation of $\mathrm{NO}$ into $\mathrm{NO}_{2}$ over Pt/MPS (honeycomb) with $\mathrm{O}_{2}:(\bullet)$ and $(\boldsymbol{\Delta})$ depict the $\mathrm{NO}$ ratio and $\mathrm{NO}_{2}$ ratio, respectively; (---) the equilibrium between $\mathrm{NO}_{2}$ and $\mathrm{NO}$ (ref. [5]). The result of the second stage is also shown: (०) NOxconversion by injection of $\mathrm{C}_{3} \mathrm{H}_{6}$ into the first stage outlet-gas.

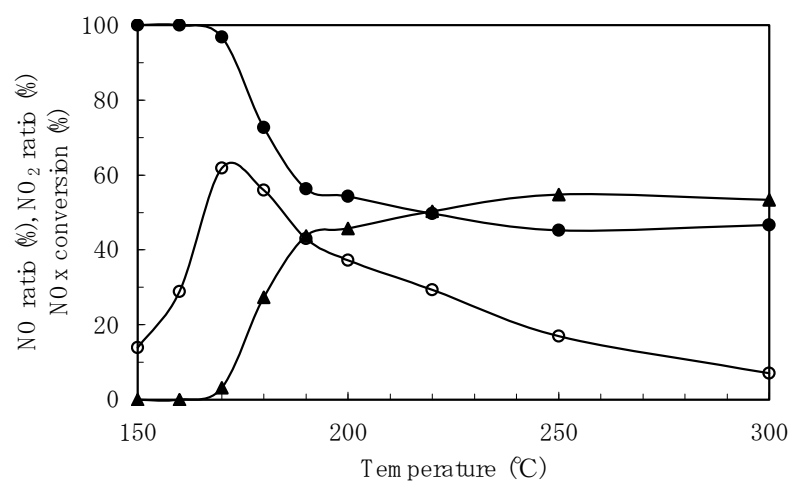

Fig. (5b). $\left[2^{\text {nd }}\right.$ stage $]$ reduction of the $1^{\text {st }}$ stage outlet-gas over Pt/MPS (honeycomb) with propylene: $(\bullet)$ and $(\boldsymbol{\Delta})$ depict the NO ratio and $\mathrm{NO}_{2}$ ratio, respectively; (०) NOx-conversion.

\section{HC-SCR of Lean-NOx over Pt/MPS with Long-Chain HCs}

Fig. (6) shows the purification of NOx over Pt/MPS using model-gas (2). The results show that Pt/MPS is able to perfectly purify lean NOx with stoichiometric HCs (where, stoichiometric $\mathrm{HCs}$ mean the quantitative $\mathrm{HCs}$ required for the perfect consumption of $\mathrm{HC}$ with $10 \% \mathrm{O}_{2}$ ) above $170{ }^{\circ} \mathrm{C}$. The apparent order of the reducing activities among the hydrocarbons (in regard to the temperature acting as a reducing agent of NOx) was propylene $(100 \%$ in NOxconversion at $\left.170{ }^{\circ} \mathrm{C}\right)$ and n-octane $\left(100 \%\right.$ at $\left.170{ }^{\circ} \mathrm{C}\right)$
$>$ n-cetane $\left(100 \%\right.$ at $\left.180{ }^{\circ} \mathrm{C}\right)>$ light oil $\left(100 \%\right.$ at $\left.200{ }^{\circ} \mathrm{C}\right)$ and toluene $\left(100 \%\right.$ at $\left.200{ }^{\circ} \mathrm{C}\right)$. The NOx-conversion curves and the hydrocarbon-consumption curves were synchronized with each other. The steep slope $[\Delta$ (NOx-conversion) $/ \Delta \mathrm{T}]$ of each NOx-conversion curve is almost the same $10 \% \mathrm{~K}^{-1}$ for each HC. The results show that the HC-SCR of lean NOx with stoichometric HCs proceeds rapidly with the catalytic consumption of HCs. Many HCs are combustible over Pt/MPS with excess amounts of oxygen at comparatively mild temperatures. The difference in reducing activity among HCs is not clearly associated with the chain-length of HCs. Most aliphatic and aromatic HCs can be used as the reducing agents for lean NOx over Pt/MPS.

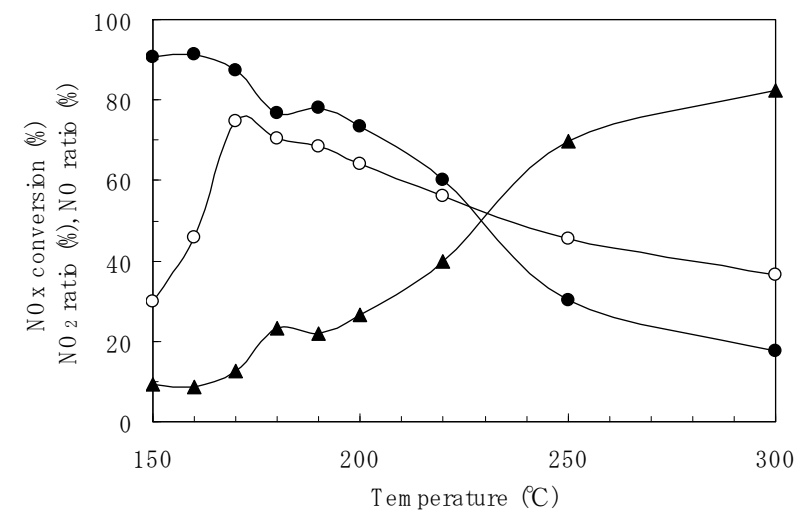

Fig. (5c). HC-SCR of $\mathrm{NO}_{2}$ over Pt/MPS (honeycomb) with model-

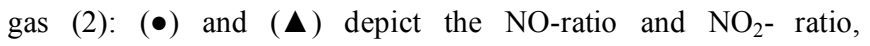
respectively; (०) NOx-conversion.

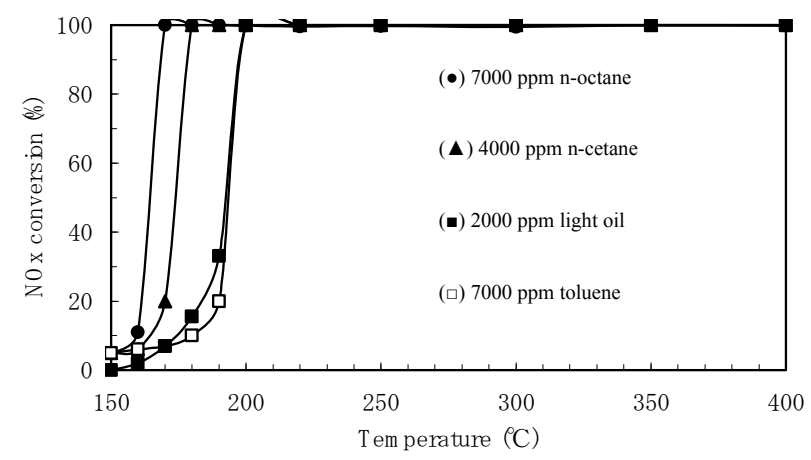

Fig. (6). HC-SCR of lean NOx over Pt/MPS (honeycomb) with model-gas (3) containing long chain HCs. 


\section{CONCLUSION}

The HC-SCR of lean NOx at low temperatures below $200{ }^{\circ} \mathrm{C}$ was remarkably improved using the Pt-catalyst supported on mesoporous silica (Pt/MPS). Such remarkable low-temperature activity of Pt/MPS is primarily due to the acidity of MPS rather than the sizes of Pt-particles and mesopores. The kinetic investigation of HC-SCR of NOx over Pt/MPS elucidated that the NOx-conversion below 200 ${ }^{\circ} \mathrm{C}$ is determined by the oxidation of $\mathrm{NO}$ to $\mathrm{NO}_{2}$ which is the rate-determining step. The acid-treatment of the supports generates new functional groups assignable to active protons incorporated with the supports and makes the Pt-catalysts increase the activities. The active protons on the supports which may be acting as the Brpnsted-acid sites probably influence the rate-determining step. It was also found that the HC-SCR of lean NOx is perfectly achieved with stoichiometric $\mathrm{C}_{6}-\mathrm{C}_{16} \mathrm{HCs}$ over a wide temperature range from $170{ }^{\circ} \mathrm{C}$ to $400{ }^{\circ} \mathrm{C}$. The present HC-SCR must be very useful for de-NOx of diesel-exhaust by means of pulseinjection of diesel-fuel into the exhaust.

\section{REFERENCES}

[1] Narula, C. K.; Daw, C. S.; Hoard, J. W.; Hammer, T. Materials issues related to cataltsts for treatment of diesel exhaust. Int. J. Appl. Ceram. Technol., 2005, 2, 452-466.

[2] Iwamoto, M.; Yahiro, H. Novel catalytic decomposition and reduction of NO. Catal. Today, 1994, 22, 5-18.

[3] Bell, V. A.; Feeley, J. S.; Deeba, M.; Farrauto, R. J. In situ high temperature FTIR studies of NOx reduction with propylene over Cu/ZSM-5 catalyst. Catal. Lett., 1994, 29, 15-26.

[4] Burch, R.; Millington, P. J. Selective reduction of nitrogen oxides by hydrocarbons under lean-burn conditions using supported platinum group metal catalysts. Catal. Today, 1995, 26, 185-206.

[5] Iwamoto, M.; Fernandez, A. M.; Zengyo, T. Oxidation of NO to $\mathrm{NO}_{2}$ on Pt-MFI zeolite and subsequent reduction of NOx by $\mathrm{C}_{2} \mathrm{H}_{4}$ on In-MFI zeolite: a novel de-NOx strategy in excess oxygene. Chem. Commun., 1997, 37-38.
[6] Shichi, A.; Satsuma, A.; Iwase, M.; Shimizu, K.; Komai, S., Hattori, T. Catalyst effectiveness factor of cobalt-exchanged mordenites for the selective catalytic reduction of NO with hydrocarbons. Appl. Catal. B-Environ., 1998, 17, 107-113.

[7] Burch, R.; Watling, T. C. The effect of sulphur on the reduction of $\mathrm{NO}$ by $\mathrm{C}_{3} \mathrm{H}_{6}$ and $\mathrm{C} 3 \mathrm{H} 8$ over $\mathrm{Pt} / \mathrm{Al}_{2} \mathrm{O}_{3}$ under lean-burn conditions. Appl. Catal. B-Environ., 1998, 17, 131-139.

[8] Schießer, W.; Vinek, H.; Jentys, A. Catalytic reduction of $\mathrm{NO}_{2}$ over transition-metal containing MCM-41. Catal. Lett., 1998, 56, 189194.

[9] Iwamoto, M.; Zengyo, T.; Hernandez, A. M.; Araki, H. Intermediate addition of reductant between an oxidation and a reduction catalyst for highly selective reduction of NO in excess oxygen. Appl. Catal. B-Environ., 1998, 17, 259-266.

[10] Nakatsuji, T.; Yasukawa, R.; Tabata, K.; Ueda, K.; Niwa, M. Catalytic reduction system of NOx in exhaust gases from diesel engines with secondary fuel injection. Appl. Catal. B-Environ., 1998, 17, 333-345.

[11] Centi, G.; Perathoner, S. Novel catalyst design for multiphase reactions. Catal. Today, 2003, 79-80, 3-13.

[12] Irfan, M. F.; Goo, J. H.; Kim, S. D. $\mathrm{Co}_{3} \mathrm{O}_{4}$ based catalysts for $\mathrm{NO}$ oxidation and NOx reduction in fast SCR process. Appl. Catal. BEnviron., 2008, 78, 267-274

[13] Komatsu, T.; Tomokuni, K; Yamada, I. Outstanding low temperature $\mathrm{HC}-\mathrm{SCR}$ of $\mathrm{NOx}$ over platinum-group catalysts supported on mesoporous materials expecting diesel-auto emission regulation. Catal. Today, 2006, 116, 244-249.

[14] Ioan, B.; Miyazaki, A.; Aika, K. On the kinetic and structure sensitivity of lean reduction of $\mathrm{NO}$ with $\mathrm{C}_{3} \mathrm{H}_{6}$ over nanodispersed Pt catalysts. Appl. Catal. B-Environ., 2005, 59, 71-80.

[15] Bueno-Lopez, A.; Illan-Gomez, M. J.; Salinas-Martinez de Lecea, C. Effect of $\mathrm{NOx}$ and $\mathrm{C}_{3} \mathrm{H}_{6}$ partial pressures on the activity of Ptbeta-coated cordierite monoliths for deNOx $\mathrm{C}_{3} \mathrm{H}_{6}$-SCR. Appl. Catal. A-General, 2006, 302, 244-249.

[16] Botas, J. A.; Miguel, A.; Gutierrez-Ortiz, M. P.; Gonzalez-Marcos, J. A.; Gonzalez-Marcos, J. R.; Gonzalez-Velasco, Kinetic considerations of three-way catalysis in automobile exhaust converters. Appl. Catal. B-Environ., 2001, 32, 243-256.

[17] Marnellos, G. E.; Efthimiadis, E. A.; Vasalos, I. A. Mechanistic and kinetic analysis of the NOx selective catalytic reduction by hydrocarbons in excess $\mathrm{O}_{2}$ over In/ $/ \mathrm{Al}_{2} \mathrm{O}_{3}$ in the presence of $\mathrm{SO}_{2}$ and $\mathrm{H}_{2} \mathrm{O}$. Appl. Catal. B-Environ., 2004, 48, 1-15. 